\title{
Impact of Age and Body Site on Adult Female Skin Surface pH
}

\author{
Stephan Schreml ${ }^{\mathrm{a}}$ Veronika Zeller ${ }^{\mathrm{a}}$ Robert Johannes Meier ${ }^{\mathrm{b}}$ \\ Hans Christian Korting ${ }^{c}$ Barbara Behm ${ }^{a}$ Michael Landthaler ${ }^{a}$ \\ Philipp Babilas ${ }^{\text {a }}$ \\ ${ }^{a}$ Department of Dermatology, University Hospital Regensburg, and ${ }^{\mathrm{b}}$ Institute of Analytical Chemistry, \\ Chemo- and Biosensors, University of Regensburg, Regensburg; ' ${ }^{\mathrm{C}}$ Department of Dermatology, \\ Ludwig Maximilians University Munich, Munich, Germany
}

\section{Key Words}

Skin care $\cdot$ Aging $\cdot$ Anti-aging $\cdot$ Cosmetics $\cdot$ Epidermal barrier

\begin{abstract}
Background: $\mathrm{pH}$ is known as an important parameter in epidermal barrier function and homeostasis. Aim: The impact of age and body site on skin surface $\mathrm{pH}\left(\mathrm{pH}_{\mathrm{ss}}\right)$ of women was evaluated in vivo. Methods: Time domain dual lifetime referencing with luminescent sensor foils was used for $\mathrm{pH}_{\mathrm{sS}}$ measurements. $\mathrm{pH}_{\mathrm{ss}}$ was measured on the forehead, the temple, and the volar forearm of adult females ( $n=97,52.87$ \pm 18.58 years, $20-97$ years). Every single measurement contained $2,500 \mathrm{pH}$ values due to the luminescence imaging technique used. Results: $\mathrm{pH}_{\mathrm{SS}}$ slightly increases with age on all three investigated body sites. There are no significant differences in $\mathrm{pH}_{\mathrm{SS}}$ between the three investigated body sites. Conclusion: Adult $\mathrm{pH}_{\mathrm{ss}}$ on the forehead, the temple and the volar forearm increases slightly with age. This knowledge is crucial for adapting medical skin care products.
\end{abstract}

Copyright $\odot 2012$ S. Karger AG, Basel
(C) 2012 S. Karger AG, Basel

$1018-8665 / 12 / 2241-0066 \$ 38.00 / 0$

Fax +4161306 1234

E-Mail karger@karger.ch

www.karger.com
Accessible online at: www.karger.com/drm

\section{Introduction}

Skin $\mathrm{pH}$ is known as an important parameter in skin integrity, epidermal barrier function, and wound healing $[1,2]$. Regarding skin surface $\mathrm{pH}\left(\mathrm{pH}_{\mathrm{SS}}\right)$ there are obviously diverging data available in the literature. To our knowledge, the lowest reported $\mathrm{pH}_{\mathrm{SS}}$ range is given with 4.0-5.5 [3]. The full $\mathrm{pH}_{\mathrm{SS}}$ spectrum reported in the literature ranges from as low as 4.0 up to 6.3 as reviewed by Lambers et al. [4]. In contrast, according to the prevailing medical doctrine the $\mathrm{pH}_{\mathrm{SS}}$ spectrum ranges from 5.4 to 5.9 [5]. In terms of site-specific differences in $\mathrm{pH}_{\mathrm{SS}}$ there is no clear evidence in the literature either. Some studies have reported differences [6,7], whereas others have failed to confirm this assumption [8]. Besides, there is still controversy as regards the impact of age and different body sites on $\mathrm{pH}_{\mathrm{SS}}$.

Skin acidification is crucial for epidermal barrier function and antimicrobial capacity $[1,2]$. Elevated stratum corneum (SC) $\mathrm{pH}\left(\mathrm{pH}_{\mathrm{SC}}\right)$ leads to an alteration of epidermal barrier homeostasis by degradation of corneodesmosomes, resulting in impaired SC integrity and decreased activity of lipid-processing enzymes, which require extracellular acidity for activation [9-13]. Behne et al. found the sodium-proton exchanger NHE1 to be an 
Table 1. Changes in epidermal barrier function during aging

\begin{tabular}{|c|c|c|}
\hline Reference & Study population (age) & Findings \\
\hline $\begin{array}{l}\text { Behne et al. } \\
(2003) \text { [17] }\end{array}$ & neonatal rats (days $1-7, \mathrm{n}=11-15$ ) & $\begin{array}{l}1 \text { less acidic skin surface } \mathrm{pH} \text { in newborns } \\
2 \text { skin surface } \mathrm{pH} \text { drops on day } 4 \text { and reaches adult levels on } \\
\text { day } 7 \\
3 \text { initial acidification in the lower stratum corneum with } \\
\text { outward progression }\end{array}$ \\
\hline $\begin{array}{l}\text { Choi et al. } \\
(2007) \text { [16] }\end{array}$ & $\begin{array}{l}\text { young humans }(13-21 \text { years, } \mathrm{n}=65) \text { versus } \\
\text { aged humans }(51-80 \text { years, } \mathrm{n}=55) \\
\text { young mice }(8-12 \text { weeks, } \mathrm{n}=6) \text { versus } \\
\text { aged mice }(12-15 \text { months, } \mathrm{n}=6)\end{array}$ & $\begin{array}{l}1 \text { decrease of stratum corneum acidity with age } \\
2 \text { impaired epidermal barrier recovery in aged epidermis } \\
3 \text { normal epidermal lipid synthesis in aged murine epidermis } \\
4 \text { abnormal lipid processing and stratum corneum integrity in } \\
\text { aged murine epidermis } \\
5 \text { decreased NHE1 expression in aged murine epidermis }\end{array}$ \\
\hline
\end{tabular}

\begin{tabular}{|c|c|c|}
\hline $\begin{array}{l}\text { Fluhr et al. } \\
(2000)[18]\end{array}$ & $\begin{array}{l}\text { parents }(21-44 \text { years, } \mathrm{n}=44) \text { versus } \\
\text { their children }(1-6 \text { years, } \mathrm{n}=44)\end{array}$ & average skin $\mathrm{pH}$ value of 4.91 in children vs. 5.07 in parents \\
\hline $\begin{array}{l}\text { Ghadially et al. } \\
\text { (1995) [9] }\end{array}$ & $\begin{array}{l}\text { young humans }(20-30 \text { years, total } n=15 \text {, for } \\
\text { barrier recovery } n=5) \text { versus } \\
\text { aged humans }(>80 \text { years, total } n=6 \text {, for barrier } \\
\text { recovery } n=5) \\
\text { young mice }(6-10 \text { weeks, } n=5 \text { for lipid } \\
\text { analysis, } n=10 \text { for barrier recovery) versus } \\
\text { aged mice }(18-24 \text { months, } n=5 \text { for lipid } \\
\text { analysis, } n=10 \text { for barrier recovery) }\end{array}$ & $\begin{array}{ll}1 & \text { delayed epidermal barrier recovery in aged human epidermis } \\
2 & \text { decreased transepidermal water loss in aged epidermis } \\
3 & \text { decrease in lipid content in aged vs. young murine epidermis }\end{array}$ \\
\hline $\begin{array}{l}\text { Ghadially et al. } \\
\text { (1996) [19] }\end{array}$ & aged mice ( $\geq 18$ months, $\mathrm{n}=3-7$ ) & $\begin{array}{l}\text { decrease of stratum corneum lipid content and extracellular } \\
\text { bilayers in aged murine epidermis }\end{array}$ \\
\hline $\begin{array}{l}\text { Giusti et al. } \\
(2001)[20]\end{array}$ & $\begin{array}{l}\text { infants }(8-24 \text { months, } \mathrm{n}=70) \text { versus young } \\
\text { women }(25-35 \text { years, } \mathrm{n}=30)\end{array}$ & $\begin{array}{l}1 \text { no difference in skin surface } \mathrm{pH} \text { according to sex and age in } \\
\text { infants } \\
2 \text { significantly lower skin surface } \mathrm{pH} \text { in infants versus adults, } \\
\text { no significant difference in transepidermal water loss } \\
\text { between infants and adults }\end{array}$ \\
\hline $\begin{array}{l}\text { Hoeger and } \\
\text { Enzmann } \\
(2002)[21]\end{array}$ & $\begin{array}{l}\text { neonates ( } 3 \text { days, } 4 \text { and } 12 \text { weeks, total } \\
\mathrm{n}=202 \text { ) }\end{array}$ & $\begin{array}{l}1 \text { skin surface } \mathrm{pH} \text { decrease from day } 3 \text { to } 12 \text { weeks } \\
2 \text { no significant difference in skin surface } \mathrm{pH} \text { between male } \\
\text { and female infants }\end{array}$ \\
\hline $\begin{array}{l}\text { Wilhelm et al. } \\
\text { (1991) [22] }\end{array}$ & $\begin{array}{l}\text { young humans }(20-30 \text { years, } \mathrm{n}=14) \text { versus } \\
\text { aged humans }(55-85 \text { years, } \mathrm{n}=15)\end{array}$ & $\begin{array}{l}1 \text { no significant differences between the two groups for skin } \\
\text { surface pH on most anatomic locations } \\
2 \text { significantly lower transepidermal water loss in the older } \\
\text { group }\end{array}$ \\
\hline $\begin{array}{l}\text { Ye et al. } \\
(2002)[23]\end{array}$ & $\begin{array}{l}\text { young mice }(8-12 \text { weeks, } \mathrm{n}=5) \text { versus } \\
\text { aged mice }(23-27 \text { months, } \mathrm{n}=5)\end{array}$ & $\begin{array}{l}\text { deficiency in IL- } 1 \text { signaling in aged epidermis contributing to } \\
\text { epidermal barrier abnormalities }\end{array}$ \\
\hline $\begin{array}{l}\text { Yosipovitch et al. } \\
(2000)[24]\end{array}$ & neonates $(1$ and 2 days, $\mathrm{n}=44$ ) & significantly lower skin surface $\mathrm{pH}$ on day 2 versus day 1 \\
\hline
\end{tabular}

essential regulator of $\mathrm{pH}_{\mathrm{SC}}$ [14]. Due to altered skin barrier function in aged skin, skin diseases such as xerosis cutis and pruritus are affected by the supposedly age-dependent changes in $\mathrm{pH}_{S S}[15]$. Choi et al. showed that the increased vulnerability of aged skin is due to abnormal SC acidity, resulting in defective lipid processing and loss of SC integrity [16]. Table 1 summarizes known changes in epidermal barrier function during aging $[9,16-24]$, which may affect $\mathrm{pH}_{\mathrm{SC}}$ and $\mathrm{pH}_{\mathrm{SS}}$.

To examine the effects of age, body site and UV exposure on $\mathrm{pH}_{\mathrm{SS}}$, we used a luminescence-based method for $\mathrm{pH}$ detection as previously described by our group [25]. 
Fig. 1. Representative pseudocolor images of $\mathrm{pH}_{\mathrm{SS}}$ on the volar forearm of a 24-yearold (a) and an 82-year-old woman (b). Relatively uniform distribution of $\mathrm{pH}_{\mathrm{SS}}$ is seen in the investigated areas. The mean $\mathrm{pH}_{\mathrm{SS}}$ values (central $50 \times 50$ pixels squares) were 4.39 (a) and 5.49 (b).

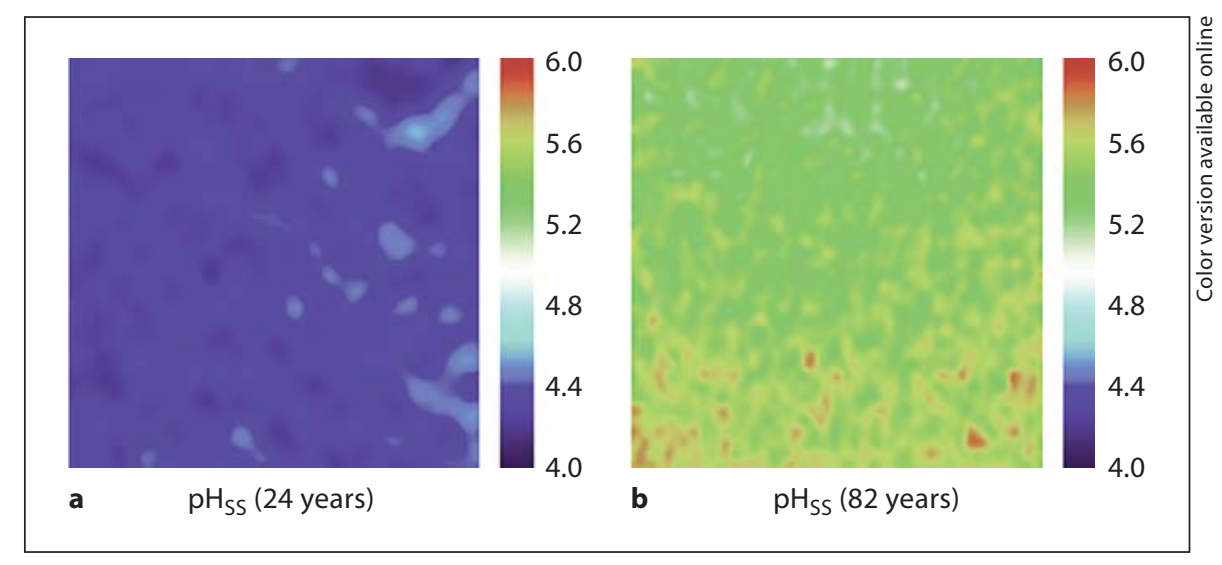

$\mathrm{pH}_{\mathrm{SS}}$ was recorded on three body sites: forehead, temple (both chronically UV-exposed) and volar forearm (virtually UV-unexposed). Data obtained from female volunteers (20-97 years) were analyzed.

\section{Subjects and Methods}

Preparation of Microparticles and Sensor Foils

In short, fluorescein isothiocyanate (FITC, Sigma-Aldrich Chemie GmbH, Talkirchen, Germany) was covalently conjugated to aminocellulose (AC) particles (Presens, Regensburg, Germany) to form FITC-AC $\mathrm{pH}$ indicator particles $[25,26]$. Reference particles were synthesized by incorporating ruthenium(II) tris-(4,7-diphenyl-1,10-phenanthroline) $\left(\mathrm{Ru}(\mathrm{dpp})_{3}\right.$, Sigma-Aldrich) in polyacrylonitrile (PAN) (Sigma-Aldrich) to form $\mathrm{Ru}(\mathrm{dpp})_{3}$-PAN particles [25, 27]. FITC-AC and $\mathrm{Ru}(\mathrm{dpp})_{3}-\mathrm{PAN}$ (3:1) were mixed with $20 \mathrm{ml}$ of a solution consisting of polyurethane hydrogel (Cardiotech International Inc., Wilmington, Mass., USA) in ethanol/water $(90 / 10 \mathrm{v} / \mathrm{v})[25,28]$. This mixture was then spread on a transparent poly(vinylidene-chloride) (PVdC) foil (Saran plastic wrap, Dow Chemicals, Midland, Mich., USA). In previous works [25], we showed (i) that dyes do not leak out of the sensor particles, (ii) that sensor particles do not leak out of the polyurethane hydrogel matrix in which they are immobilized on inert PVdC foils, and (iii) that sensor particles are neither directly cytotoxic nor quickly taken up by human epidermal keratinocytes and L929 fibroblasts. Thus, biocompatible sensor foils were used for all measurements. For a detailed description of microparticle and sensor foil preparation, we refer to our methodology paper [25].

\section{pH Measurement}

$\mathrm{pH}$ was recorded with luminescent sensor foils. For luminescence imaging (distance from camera to skin $8 \mathrm{~cm}$, focus-controlled) we used data from standard-sized squares (triplicate samples of $50 \times 50$ pixels).

In short, luminescence intensity ratios $R$ were calculated for each pixel according to the time domain dual lifetime referencing method we described previously [25, 29]. Means of $R$ were then computed for the respective area. Foils were calibrated and a five- parametric sigmoidal fit was performed. The resulting equation was then solved for $\mathrm{pH}$, thus enabling us to calculate $\mathrm{pH}$ and the respective $\mathrm{H}^{+}$concentration based on $R$ [25].

The camera was combined with a quickly pulsating, lightemitting $460 \mathrm{~nm}$ LED array (Luxeon V Star LXHL-LB5C, Lumileds Lighting Company, San Jose, Calif., USA). To image 2D $\mathrm{pH}$, time domain dual lifetime referencing detection [29] was performed using an ImageX Time Gated Imaging system (TGI, Photonic Research Systems, Salford, UK) with an integrated 12 bit CCD chip $(640 \times 480$ pixels). For details we refer to our methodology paper [25]. Calculations were performed with ImageX software (Microsoft Corporation, Redmond, Wash., USA). Representative pseudocolor images of $\mathrm{pH}_{\mathrm{SS}}$ on the volar forearm of two women (fig. 1) were created with ImageJ (http://rsbweb.nih.gov/ ij/).

\section{Study Subjects}

Female volunteers $(\mathrm{n}=97,52.87 \pm 18.58$ years, $20-97$ years $)$ were included. Volunteers did not exercise, wash or apply topical formulations on the investigated body sites for $24 \mathrm{~h}$ prior to measurements. Such standardized conditions are of major importance for studies on $\mathrm{pH}_{\mathrm{SS}}$ as routine procedures like showering with plain tap water ( $\mathrm{pH}$ about 8 in many European countries) increase the $\mathrm{pH}_{\mathrm{SS}}$ over at least $4 \mathrm{~h}$ [4]. Apart from that, $\mathrm{pH}_{\mathrm{SS}}$ is influenced by detergents and other skin cleansing agents [30,31]. All participants were provided with verbal as well as written information on the study and signed informed consent was obtained from each participant. All experiments were conducted in full accordance with the current revision (Seoul, Korea, 2008) of the Declaration of Helsinki (1964).

\section{Statistics}

We used Sigma Plot 11.0 (Systat Software Inc., Chicago, Ill., USA) for all analyses. Data are given as mean \pm standard deviation (SD) except otherwise denoted. Means were calculated from the respective $\mathrm{H}^{+}$concentrations, which were obtained for each pixel square. Subsequently, mean $\mathrm{pH}$ values were calculated from mean $\mathrm{H}^{+}$concentrations. We did linear regression analyses for age dependency of $\mathrm{pH}_{\mathrm{SS}}$. Kruskal-Wallis ANOVA on ranks was performed to analyze differences between $\mathrm{H}^{+}$concentrations for the different body sites. 


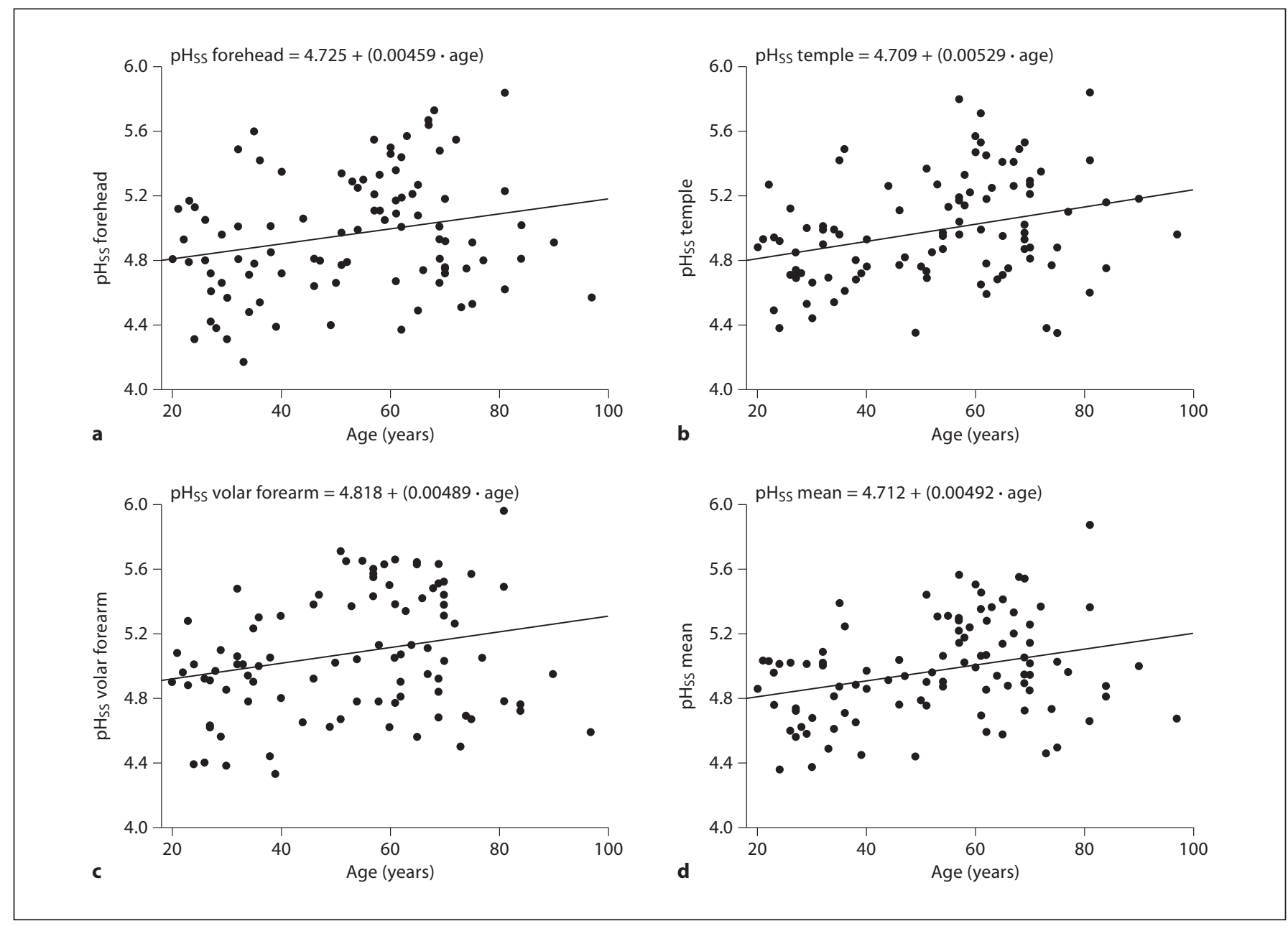

Fig. 2. $\mathrm{pH}_{\mathrm{SS}}$ versus age. A slight increase in $\mathrm{pH}_{\mathrm{SS}}$ with age was seen on the forehead (a), on the temple (b), on the volar forearm (c) and for the combined means of all three body sites (d). $\mathrm{pH}_{\mathrm{SS}}$ values show a high variability for all ages. $\mathrm{n}=97$, all female.

\section{Results}

$\mathrm{pH}_{\mathrm{SS}}$ slightly increased with age on the three investigated body sites (fig. $2 \mathrm{a}-\mathrm{c}$ ). Mean $\mathrm{pH}_{\mathrm{SS}}$ amounted to 4.8 \pm 0.4 on the forehead, and $\mathrm{pH}_{\mathrm{SS}}$ on the forehead ranged from 4.2 (33-year-old woman) to 5.8 (81-year-old woman) (fig. 2a). Mean $\mathrm{pH}_{\mathrm{SS}}$ amounted to $4.9 \pm 0.3$ on the temple, and $\mathrm{pH}_{\mathrm{SS}}$ on the temple ranged from 4.2 (49-year-old woman) to 5.8 (81-year-old woman) (fig. 2b). Mean $\mathrm{pH}_{\mathrm{SS}}$ amounted to $4.9 \pm 0.4$ on the volar forearm, and $\mathrm{pH}_{\mathrm{SS}}$ on the forearm ranged from 4.3 (39-year-old woman) to 6.0 (81-year-old woman) (fig. 2c). Mean $\mathrm{pH}$ of the three body sites also increased slightly with age (fig. $2 \mathrm{~d}$ ). Mean $\mathrm{pH}_{\mathrm{SS}}$ of all three body sites amounted to $4.9 \pm 0.3$, and mean $\mathrm{pH}_{\mathrm{SS}}$ ranged from 4.4 (24-year-old woman) to 5.9 (81-year- old woman) (fig. 2d). There were no significant differences between $\mathrm{pH}_{\mathrm{SS}}$ on the three investigated body sites $(\mathrm{p}=0.113)$.

\section{Conclusions}

In this work we show that $\mathrm{pH}_{\mathrm{SS}}$ slightly increases with age. Furthermore, there were no significant differences between $\mathrm{pH}_{\mathrm{SS}}$ on the forehead, the temple and the volar forearm. As there was no significant difference between the $\mathrm{pH}_{\mathrm{SS}}$ in sun-exposed skin (forehead, temple) as compared to sun-shielded skin (volar forearm), it seems to be unlikely that chronic exposure to UV light induces $\mathrm{pH}_{\mathrm{SS}}$ changes in human skin. Here, a moderate difference of 
$\mathrm{pH}_{\mathrm{SS}}$ in aged versus young females was detected at the three investigated body sites.

In a previous study, Ghadially et al. observed an abnormal barrier recovery in aged compared to younger human epidermis [9]. Moreover, aged epidermis exhibits a decreased rate of transepidermal water loss, abnormal cytokine/growth factor signaling and a reduction in epidermal lipid synthesis [18, 32]. Interestingly, the omega-3 polyunsaturated fatty acid 11,14,17-eicosatrienoic acid was found to be increased in photoaged human epidermis and also after UV irradiation, whereas a decrease was found in intrinsically aged human epidermis [33]. A deficiency of IL-1 signaling in murine aged epidermis, which may contribute to epidermal barrier abnormality, has been reported by Ye et al. [23]. An improvement in barrier recovery has been achieved with the administration of imiquimod to aged murine skin, as imiquimod induces an alteration in multiple cytokine pathways, in- cluding an increase in IL- $1 \alpha$ levels, and this seems to improve barrier recovery in aged epidermis $[23,34]$.

The future will show whether an adaptation of $\mathrm{pH}$ in topical therapeutics and skin care products is of benefit for patients and customers of these products.

\section{Acknowledgements}

The authors dedicate this paper to the memory of Hans Christian Korting, sadly deceased on February 25, 2012. The authors are grateful for grants from the German Research Foundation (Deutsche Forschungsgemeinschaft DFG, BA 3410/3-1, BA 3410/4-1 and WO 669/9-1) and the Novartis Foundation (S.S., Novartis Graduate Scholarship).

\section{Disclosure Statement}

The authors have no competing financial interests to disclose.

\section{References}

1 Schreml S, Szeimies RM, Karrer S, Heinlin J, Landthaler M, Babilas P: The impact of the $\mathrm{pH}$ value on skin integrity and cutaneous wound healing. J Eur Acad Dermatol Venereol 2010;24:373-378.

2 Schmid-Wendtner MH, Korting HC: The $\mathrm{pH}$ of the skin surface and its impact on the barrier function. Skin Pharmacol Physiol 2006; 19:296-302.

3 Dikstein S, Zlotogorski A: Measurement of skin $\mathrm{pH}$. Acta Derm Venereol Suppl (Stockh) 1994;185:18-20.

4 Lambers H, Piessens S, Bloem A, Pronk H, Finkel P: Natural skin surface $\mathrm{pH}$ is on average below 5 , which is beneficial for its resident flora. Int J Cosmet Sci 2006;28:359-370.

5 Braun-Falco O, Korting HC: Normal pH value of human skin (in German). Hautarzt 1986;37:126-129.

6 Yosipovitch G, Xiong GL, Haus E, SackettLundeen L, Ashkenazi I, Maibach HI: Timedependent variations of the skin barrier function in humans: transepidermal water loss, stratum corneum hydration, skin surface $\mathrm{pH}$, and skin temperature. J Invest Dermatol 1998; 110:20-23.

7 Zlotogorski A: Distribution of skin surface $\mathrm{pH}$ on the forehead and cheek of adults. Arch Dermatol Res 1987;279:398-401.

8 Fluhr JW, Dickel H, Kuss O, Weyher I, Diepgen TL, Berardesca E: Impact of anatomical location on barrier recovery, surface $\mathrm{pH}$ and stratum corneum hydration after acute barrier disruption. Br J Dermatol 2002;146:770776.
9 Ghadially R, Brown BE, Sequeira-Martin SM, Feingold KR, Elias PM: The aged epidermal permeability barrier. Structural, functional, and lipid biochemical abnormalities in humans and a senescent murine model. J Clin Invest 1995;95:2281-2290.

10 Hachem JP, Crumrine D, Fluhr J, Brown BE, Feingold KR, Elias PM: pH directly regulates epidermal permeability barrier homeostasis, and stratum corneum integrity/cohesion. J Invest Dermatol 2003;121:345-353.

11 Mauro T, Holleran WM, Grayson S, Gao WN, Man MQ, Kriehuber E, Behne M, Feingold KR, Elias PM: Barrier recovery is impeded at neutral $\mathrm{pH}$, independent of ionic effects: implications for extracellular lipid processing. Arch Dermatol Res 1998;290: 215-222.

12 Schmuth M, Man MQ, Weber F, Gao W, Feingold KR, Fritsch P, Elias PM, Holleran WM: Permeability barrier disorder in Niemann-Pick disease: sphingomyelin-ceramide processing required for normal barrier homeostasis. J Invest Dermatol 2000; 115:459-466.

13 Takagi Y, Kriehuber E, Imokawa G, Elias PM, Holleran WM: Beta-glucocerebrosidase activity in mammalian stratum corneum. J Lipid Res 1999;40:861-869.

14 Behne MJ, Meyer JW, Hanson KM, Barry NP, Murata S, Crumrine D, Clegg RW, Gratton E, Holleran WM, Elias PM, Mauro TM: NHE1 regulates the stratum corneum permeability barrier homeostasis. Microenvironment acidification assessed with fluorescence lifetime imaging. J Biol Chem 2002; 277:47399-47406.
15 Seyfarth F, Schliemann S, Antonov D, Elsner P: Dry skin, barrier function, and irritant contact dermatitis in the elderly. Clin Dermatol 2011;29:31-36.

16 Choi EH, Man MQ, Xu P, Xin S, Liu Z, Crumrine DA, Jiang YJ, Fluhr JW, Feingold KR, Elias PM, Mauro TM: Stratum corneum acidification is impaired in moderately aged human and murine skin. J Invest Dermatol 2007;127:2847-2856.

17 Behne MJ, Barry NP, Hanson KM, Aronchik I, Clegg RW, Gratton E, Feingold K, Holleran WM, Elias PM, Mauro TM: Neonatal development of the stratum corneum $\mathrm{pH}$ gradient: localization and mechanisms leading to emergence of optimal barrier function. J Invest Dermatol 2003;120:998-1006.

18 Fluhr JW, Pfisterer S, Gloor M: Direct comparison of skin physiology in children and adults with bioengineering methods. Pediatr Dermatol 2000;17:436-439.

19 Ghadially R, Brown BE, Hanley K, Reed JT, Feingold KR, Elias PM: Decreased epidermal lipid synthesis accounts for altered barrier function in aged mice. J Invest Dermatol 1996;106:1064-1069.

20 Giusti F, Martella A, Bertoni L, Seidenari S: Skin barrier, hydration, and $\mathrm{pH}$ of the skin of infants under 2 years of age. Pediatr Dermatol 2001;18:93-96.

21 Hoeger PH, Enzmann CC: Skin physiology of the neonate and young infant: a prospective study of functional skin parameters during early infancy. Pediatr Dermatol 2002;19: 256-262. 
22 Wilhelm KP, Cua AB, Maibach HI: Skin aging. Effect on transepidermal water loss, stratum corneum hydration, skin surface $\mathrm{pH}$, and casual sebum content. Arch Dermatol 1991;127:1806-1809.

23 Ye J, Garg A, Calhoun C, Feingold KR, Elias PM, Ghadially R: Alterations in cytokine regulation in aged epidermis: implications for permeability barrier homeostasis and inflammation. I. IL-1 gene family. Exp Dermatol 2002;11:209-216.

24 Yosipovitch G, Maayan-Metzger A, Merlob P, Sirota L: Skin barrier properties in different body areas in neonates. Pediatrics 2000; 106:105-108.

25 Schreml S, Meier RJ, Wolfbeis OS, Landthaler M, Szeimies RM, Babilas P: 2D luminescence imaging of $\mathrm{pH}$ in vivo. Proc Natl Acad Sci USA 2011;108:2432-2437.
26 Posch HE, Leiner MJP, Wolfbeis OS: Towards a gastric $\mathrm{pH}$-sensor: an optrode for the pH 0-7 range. Fresenius J Anal Chem 1989; 334:162-165.

27 Kürner JM, Klimant I, Krause C, Preu H, Wolfbeis OS: Inert phosphorescent nanospheres as markers for optical assays. Bioconjug Chem 2001;12:883-889.

28 Kocinkova AS, Nagl S, Arain S, Krause C, Borisov SM, Arnold M, Wolfbeis OS: Multiplex bacterial growth monitoring in 24-well microplates using a dual optical sensor for dissolved oxygen and $\mathrm{pH}$. Biotechnol Bioeng 2008;100:430-438.

29 Liebsch G, Klimant I, Krause C, Wolfbeis OS: Fluorescent imaging of $\mathrm{pH}$ with optical sensors using time domain dual lifetime referencing. Anal Chem 2001;73:4354-4363.

30 Korting HC, Braun-Falco O: The effect of detergents on skin $\mathrm{pH}$ and its consequences. Clin Dermatol 1996;14:23-27.
31 Korting HC, Megele M, Mehringer L, Vieluf D, Zienicke H, Hamm G, Braun-Falco O: Influence of skin cleansing preparation acidity on skin surface properties. Int J Cosmet Sci 1991;13:91-102.

32 Elias PM, Ghadially R: The aged epidermal permeability barrier: basis for functional abnormalities. Clin Geriatr Med 2002;18:103120 , vii.

33 Kim EJ, Kim MK, Jin XJ, Oh JH, Kim JE, Chung JH: Skin aging and photoaging alter fatty acids composition, including 11,14,17eicosatrienoic acid, in the epidermis of human skin. J Korean Med Sci 2010;25:980983.

34 Barland CO, Zettersten E, Brown BS, Ye J, Elias PM, Ghadially R: Imiquimod-induced interleukin-1 alpha stimulation improves barrier homeostasis in aged murine epidermis. J Invest Dermatol 2004;122:330-336. 